\title{
Interactions between Amyloid-B Proteins and Human Brain Pericytes: Implications for the Pathobiology of Alzheimer's Disease
}

\author{
Donald J. Alcendor \\ Center for AIDS Health Disparities Research, Department of Microbiology, Immunology and Physiology, \\ School of Medicine, Meharry Medical College, Nashville, TN 37208, USA; dalcendor@mmc.edu
}

Received: 9 April 2020; Accepted: 12 May 2020; Published: 15 May 2020

\begin{abstract}
Alzheimer's disease (AD) is a progressive neurodegenerative disease that is the most common cause of dementia, especially among aging populations. Despite advances in AD research, the underlying cause and the discovery of disease-modifying treatments have remained elusive. Two key features of AD pathology are the aberrant deposition of amyloid beta (amyloid- $\beta$ or $A \beta)$ proteins in the brain parenchyma and $A \beta$ toxicity in brain pericytes of the neurovascular unit/blood-brain barrier (NVU/BBB). This toxicity induces oxidative stress in pericytes and leads to capillary constriction. The interaction between pericytes and $\mathrm{A} \beta$ proteins results in the release of endothelin-1 in the pericytes. Endothelin-1 interacts with $\mathrm{ET}_{\mathrm{A}}$ receptors to cause pericyte contraction. This pericyte-mediated constriction of brain capillaries can cause chronic hypoperfusion of the brain microvasculature, subsequently leading to the neurodegeneration and cognitive decline observed in $\mathrm{AD}$ patients. The interaction between $\mathrm{A} \beta$ proteins and brain pericytes is largely unknown and requires further investigation. This review provides an updated overview of the interaction between $A \beta$ proteins with pericytes, one the most significant and often forgotten cellular components of the BBB and the inner blood-retinal barrier (IBRB). The IBRB has been shown to be a window into the central nervous system (CNS) that could allow the early diagnosis of AD pathology in the brain and the BBB using modern photonic imaging systems such as optical coherence tomography (OCT) and two-photon microscopy. In this review, I explore the regulation of $A \beta$ proteins in the brain parenchyma, their role in AD pathobiology, and their association with pericyte function. This review discusses $\mathrm{A} \beta$ proteins and pericytes in the ocular compartment of $\mathrm{AD}$ patients as well as strategies to rescue or protect pericytes from the effects of $A \beta$ proteins, or to replace them with healthy cells.
\end{abstract}

Keywords: Alzheimer's disease; pericytes; $\beta$-amyloid; blood-brain barrier; neurovascular unit; neurodegeneration; neuroinflammation; retinopathy

\section{Introduction}

Alzheimer's disease (AD) is a pervasive and progressive neurodegenerative disorder that is expected to affect 14 million people in the US by 2050, with increasing incidence in aging populations. Currently, there are no curative treatments for $\mathrm{AD}[1,2]$. While existing therapies can address the symptoms of $\mathrm{AD}$, they cannot inhibit disease progression. In fact, they only offer modest improvements in cognition and overall functioning. $\mathrm{AD}$ pathology has largely been attributed to the progressive accumulation of extracellular amyloid- $\beta$ (A $\beta$ ) proteins in the brain parenchyma, subsequently resulting in the formation of senile plaques and neurofibrillary tangles composed of hyperphosphorylated tau proteins [3,4]. These plaques also occur in vessels, causing cerebral amyloid angiopathy [4-7]. Over time, these phenomena result in neuronal damage that coincides with loss of synapses and synaptic plasticity, leading to progressive cognitive impairment and dementia. 
Epidemiologic studies have uncovered a vascular component in the development of AD [8]. One of the most prominent initial changes in AD pathology is a decrease in cerebral blood flow (CBF) [8]. Since vascular resistance in the brain parenchyma is associated with capillaries, cerebral pericytes may play a role in the development of AD [9]. The human blood-brain barrier (BBB) consists of brain microvascular endothelial cells, brain pericytes, and astrocytes; together, they form the neurovascular unit (NVU) [10-12]. Pericytes of the BBB play an essential role in several microvascular functions, including angiogenesis, vascular remodeling, and the regulation of microcirculation, as well as the generation and maintenance of the BBB [13-17]. Pericyte dysfunction has been observed in AD pathology [18-21]. A $\beta$ proteins induce neurovascular dysfunction, which leads to functional changes in the brain microvasculature, subsequently impairing capillaries in their response to neuronal activity [22,23]. Using human brain slices and a mouse model of AD, Nortley et al. showed that oxidative stress caused by $A \beta$ toxicity leads to capillary constriction via the generation of reactive oxygen species (ROS) by reduced nicotinamide adenine dinucleotide phosphate oxidase 4 (NOX4) [24]. These ROS then trigger the release of endothelin-1. Endothelin- 1 interacts with $\mathrm{ET}_{\mathrm{A}}$ receptors to cause pericyte contraction and subsequent capillary constriction [24]. Interestingly, the authors did not observe pericyte constriction in areas of the mouse brains with no $A \beta$ deposition [24]. Findings from this study suggest that brain vascular pericytes are the link between $A \beta$ proteins and vascular dysfunction in $\mathrm{AD}$ [24].

The underlying mechanisms that support the role of pericytes in AD pathobiology are unclear. The lack of knowledge in this regard constitutes an important information gap in our understanding of the interactions among cellular components of the NVU and A $\beta$ proteins in the development of AD. Since brain pericyte dysfunction leads to dysfunction of the NVU/BBB, pericytes play a major role in the predisposition and development of $A D$. The $A \beta_{40}$ and $A \beta_{42}$ alloforms exist in amyloid deposits in the brains of AD patients and in cerebral pericytes $[25,26]$. Perivascular drainage of A $\beta$ peptides that represent insoluble deposits in the brain parenchyma and in blood vessel walls that can lead to cerebral amyloid angiopathy (CAA) is essential [27]. More specifically, CAA involves the pathologic deposition of $A \beta$ within cortical and leptomeningeal arteries, arterioles, capillaries and, in rare cases, the venules of the brain. Dysfunction of perivascular drainage pathways to eliminate $A \beta$ in interstitial fluid (ISF) from the brain can result in intracerebral hemorrhage due to the rupture of $\mathrm{A} \beta$-laden arteries and cerebral vascular dysfunctions seen in AD patients, leading to neuronal injury, cognitive decline, and dementia [27]. The $B B B$ is the primary route of clearance for $A \beta_{40}$ and $A \beta_{42}$ [28]. $\mathrm{A} \beta$ proteins have been implicated in pericyte loss and dysfunction, leading to the BBB impairment that contributes to neurodegeneration [18-21]. A study in mice showed that $A \beta_{40}$ clearance via the BBB is mediated by scavenger receptor low-density lipoprotein receptor-related protein-1 (LRP-1) [29]. Pericyte degeneration or loss as well as LRP-1 downregulation are predominant mechanisms that compromise the $\mathrm{BBB}$ in $\mathrm{AD}$ patients and $\mathrm{AD}$ animal models [30,31].

The understanding of functional changes in brain pericytes in AD patients and the mechanisms associated with $\mathrm{AD}$ pathobiology may lead to strategies for protecting and/or preserving pericyte function. These strategies could serve as early intervention and/or treatment options that may delay, prevent, or limit AD progression. These options may also be applicable to other conditions that affect the BBB such as multiple sclerosis, strokes, and various neurological tumors including glioblastoma multiforme.

\section{A $\beta$ Proteins and Pericytes}

Coined by Virchow, the word "amyloid" was derived from the Latin word amylum and the Greek word amylon for starch that stained positive with iodine [32,33]. Friedrich and Kekule later correctly identified amyloid to consist mainly of protein and a small fraction of glycosaminoglycans [34]. All known types of AD (early-onset, late-onset, and familial) seem to involve the aberrant accumulation and/or dysfunctional clearance of $A \beta$ proteins. Amyloidosis refers to the aberrant accumulation and deposition of amyloid fibrils in the central nervous system (CNS) that are associated with 
several age-related human pathologies, including AD and Parkinson's disease. Nearly 50 unique proteins or peptides have been associated with the amyloid fibrils that exist in amyloid-based diseases [35,36]. These amyloid fibrils self-assemble and accumulate extracellularly as plaques and intracellularly as intranuclear inclusions. Nearly 40 years of research on amyloid accumulation and deposition have resulted in technologies such as cyro-electron microscopy and solid-state NMR spectroscopy that yielded the first near-atomic-resolution structures of amyloid fibrils formed in vitro [37]. Conformation-dependent antibodies have been used to separate $A \beta$ proteins into different structural classes [38-40] that may play different pathological roles in AD. These structural classes include fibrillar and prefibrillar oligomers. $A \beta_{40}$ fibrillar oligomers are small aggregates that have a high $\beta$-sheet content and are structurally similar to fibrils, with some disruptions in the $\beta$-sheet stacking [41]. Breydo et al., examined structural differences among fibrillar oligomers, prefibrillar oligomers, and fibrils using Raman, Fourier transform infrared spectroscopy (FTIR), and Circular dichroism (CD) spectroscopy. They found that fibrillar oligomers, although less stable, are structurally similar to fibrils, while prefibrillar oligomers are much less ordered [42]. These findings support previously proposed models of $A \beta$ oligomers.

The variable organization of $\alpha$-helices and $\beta$-strands in globular proteins associated with $A \beta$ proteins consists of more than 1375 distinct fold patterns [43]. This phenomenon leads to different clinical presentations involving the aggregation of the same protein, which may explain why amyloid-based diseases are so difficult to understand and treat [43]. Since the first documented case of AD in a patient by Alois Alzheimer in 1907, more than 50 disease-causing amyloidogenic proteins have been identified [44,45]. There are a multitude of genetic variants that predispose individuals to amyloid-based diseases. For instance, individuals with trisomy 21, which contains the gene encoding amyloid precursor protein (APP) from which $\mathrm{A} \beta_{40 / 42}$ are derived, are at a higher risk of AD [46]. What initiates the onset of amyloid-based diseases remains unclear. Moreover, strategies that decrease the concentration of amyloidogenic monomers to reduce amyloid load [47] or promote the sequestration of monomers into non-amyloid amorphous aggregates [48] could have deleterious effects on the normal function of these monomers. Therefore, an understanding the molecular basis for amyloid aggregation and deposition will aid the development of novel therapeutic strategies for combating amyloid-based diseases like AD.

Pericytes, also known as Roget cells or mural cells, were first described by Eberth and Rouget in the 1870s. The name "pericyte" was introduced by Zimmermann in 1923 [49-52]. Pericytes are heterogeneous, tissue-specific, and multipotent cells that are abluminal to endothelial cells. They have contractile properties due to the expression of contractile and cytoskeletal proteins such as $\alpha$-smooth muscle actin ( $\alpha$-SMA), vimentin, desmin, myosin, and nestin. These proteins enable pericytes to extend their cytoplasm to wrap around the endothelial cells lining pre-capillary arterioles and post-capillary venules throughout the body [49-52]. In culture, primary brain pericytes maintain their long cytoplasmic extensions and stain positive for neural/glial antigen-2 (NG2) (Figure 1). Although brain pericytes do not possess any unique antigenic biomarkers, they can be identified by their expression of platelet-derived growth factor receptor- $\beta$ (PDGFR $\beta$ ), $\alpha$-SMA, CD13, NG2, CD146, and desmin [53]. NG2 and CD13 are also present on vascular smooth muscle cells (vSMCs) in large vessels [53]. Unlike the vasculature of peripheral tissues, the vasculature in the retina and brain is known to have the highest pericyte-to-endothelial cell ratio $[54,55]$. The proximity of pericytes to endothelial cells facilitate signaling that is essential for vessel formation, vessel maturation, pericyte recruitment, and pericyte coverage [55]. Endothelin-1 signaling can induce the arrangement of brain vascular pericytes on capillaries (Figure 2A) in order to constrict capillaries and regulate CBF (Figure 2B). PDGF- $\beta$ secreted by endothelial cells recruits pericytes to blood vessels by binding to PDGFR $\beta$ on pericytes, causing receptor dimerization, autophosphorylation, and activation [56,57]. The human BBB consists of astrocytes, pericytes, neurons, and the extracellular matrix; together, they form the NVU [58]. Under physiological conditions in the CNS, pericytes regulate BBB integrity via the use of tight/adherens junctions and transcytosis across the BBB. Pericytes regulate angiogenesis, phagocytosis, 
the clearance of toxic metabolites from the CNS, and CBF by inducing changes in capillary diameter, neuroinflammation, and multipotent stem cell activity [59]. Proinflammatory responses at the BBB are also mediated by PDGFR $\beta$ signal transduction in pericytes [60]. Transcriptional regulation of chemokines that promote endothelial expression of monocyte chemoattractant protein-1 (MCP-1), nitric oxide (NO), IL-1, IL-6, IL-12, and tumor necrosis factor- $\alpha$ (TNF- $\alpha$ ) can influence the transvascular trafficking of macrophages and leukocytes into the brain parenchyma [59].

\section{Cultivation of primary human brain pericytes}

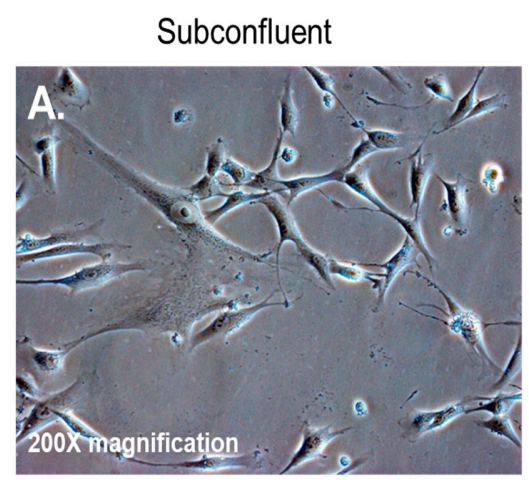

Confluent

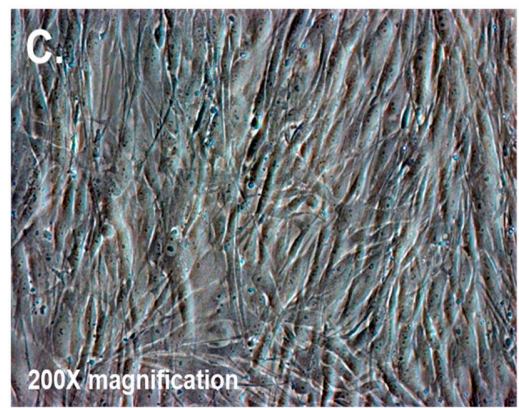

Moderately confluent

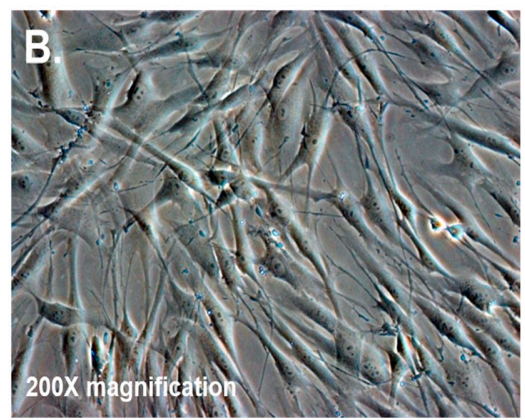

IFA for NG-2 proteoglycan

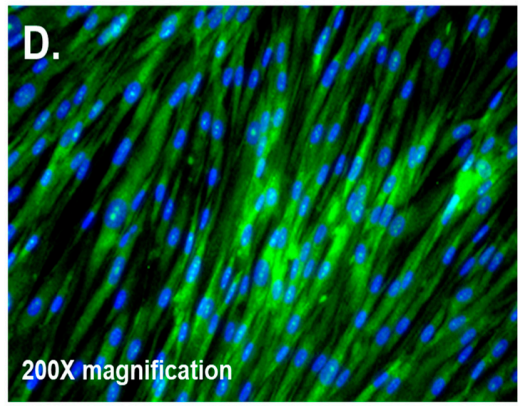

Figure 1. Brain vascular pericytes in vitro. (A-C) Primary human brain pericytes in culture, from low to high confluency; (D) primary human brain pericytes stained with a monoclonal antibody against neural/glial antigen-2 (NG2) proteoglycan. The total magnification is 200× ([17], Figure 1A,C).

Model effects of amyloid beta $(A \beta)$ induced pericyte constriction of brain capillaries

Pericytes on brain capillaries

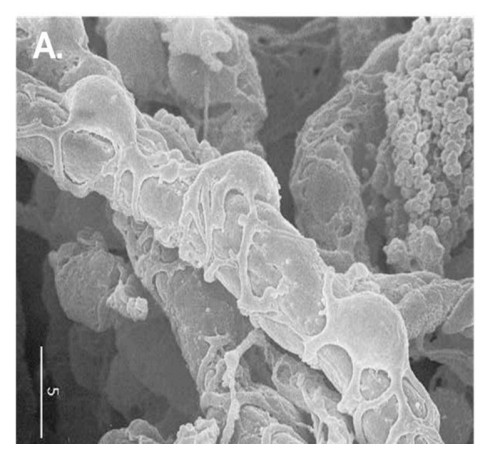

Pericytes constriction of brain capillaries

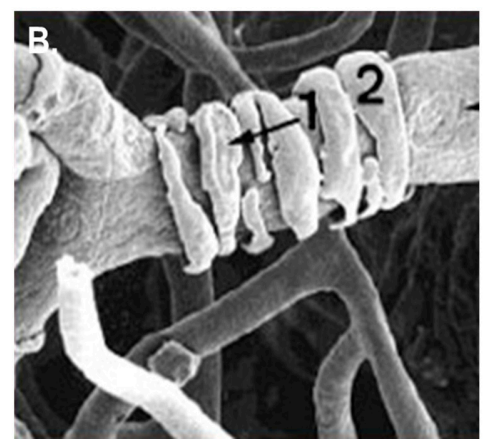

Figure 2. Brain vascular pericytes in vivo. (A) Pericytes on rat brain capillaries; (B) rat brain capillaries undergoing constriction by vascular pericytes. The marker measures 5 microns. Modified with permission from Pearson Education (unpublished data). (1) is an under configuration wrapping of pericyte extensions around the capillary; (2) is an over configuration wrapping of pericyte extensions around the capillary. 


\section{The Interaction between $A \beta$ Proteins and Brain Pericytes in AD Pathobiology}

$\mathrm{AD}$ is an amyloid- $\beta$-based disease in which a disruption in the production and clearance of $\mathrm{A} \beta$ proteins in the brain leads to $A \beta$ protein accumulation and associated pathology. The association between $A \beta$ proteins and $A D$ emerged when $A \beta$ plaques were detected in the brains of $A D$ patients (1892) and in proteinaceous fibrils (1968). The $A \beta$ species in $A D$ patients are known as $A \beta_{40}$ and $A \beta_{42}$. These proteins form insoluble, highly neurotoxic fibrils that make up the $A \beta$ plaques of which $A b_{42}$ is the major component [61]. Areas in the brain parenchyma containing $A \beta$ plaques display signs of neuroinflammation, as indicated by the presence of activated glial cells and significant neuronal loss. A study by Segillo et al. revealed significant pericyte loss in the brains of AD patients compared to those of age-matched non-demented controls [62]. In addition, the authors found that pericyte loss correlated with increased $A \beta$ deposition in the brains of AD patients and those of mice with $\mathrm{AD}[19,62]$. In vitro studies have shown reduced pericyte survival and the loss of NG2 proteoglycan after exposure to $A \beta_{42}$, as well as $A \beta_{42}$ oligomer fibrils, respectively [63-65]. Although $A b_{40}$ is less prone to aggregate and form plaques compared to $\mathrm{Ab}_{42}$, it has been shown to form deposits in the vessel wall in the development of cerebral amyloid angiopathy (CAA) [66]. In CAA, pericytes degenerate and are less likely to survive after exposure to $\mathrm{Ab}_{40}$ aggregates $[67,68]$. Most recently, Shultz et al., observed a reduced number of hippocampal NG2+ pericytes and an association between NG2+ pericyte numbers and $A \beta_{40}$ levels in $A D$ patients. The authors showed that the effects of $\mathrm{Ab}_{40}$ on $\mathrm{NG} 2+$ pericytes are aggregation dependent. Specifically, while exposure to $\mathrm{Ab}_{40}$ monomers increased pericyte viability and proliferation and reduced caspase 3/7 activity, exposure to fibril-enriched $A b_{40}$ reduced pericyte viability and proliferation and increased caspase 3/7 activity [69]. These findings suggest that the formation of $\mathrm{Ab}_{40}$ fibrils and pericyte coverage reduction at the $\mathrm{BBB}$ have a positive feedback relationship that may exacerbate parenchymal and vascular $A \beta$ accumulation.

Studies in humans have shown that up to $50 \%$ of the $A \beta$ proteins produced by neurons and other types of cells in the brain travel across the BBB to the blood [70]. Cellular components of the $\mathrm{BBB}$, including pericytes, are responsible for $\mathrm{A} \beta$ degradation and clearance via $\mathrm{BBB}$ into the blood [71]. During $A \beta$ protein transport, Low-density lipoprotein receptor-related protein 1 (LRP1), an apolipoprotein E (apoE) receptor [72,73], mediates the internalization of soluble $A \beta$ proteins at the abluminal side of the BBB [74-76] and subsequent $A \beta$ transcytosis across the BBB. Phosphatidylinositol-binding clathrin assembly protein (PICALM), as well as small GTPases Rab5 and Rab11, regulate $A \beta$ transcytosis, which results in $A \beta$ exocytosis across the luminal side of the $B B B$ into the blood [77]. Pericytes at the BBB participate in the clearance of toxic molecules and proteins, including $A \beta$ proteins that are also eliminated by perivascular drainage pathways, by which interstitial fluid (ISF) and solutes are cleared from the brain [77]. A recent study by Ma et al. using APPSw/0 mice showed that $A \beta$ proteins can accumulate in brain pericytes, underscoring the role of brain pericytes in $A \beta$ clearance at the BBB [78]. The authors also showed that pericytes internalize and clear $A \beta$ aggregates via an LRP1/apoE-specific mechanism. These findings could aid the development of novel therapeutic strategies targeting the LRP1/apoE pathway in pericytes [78].

$\mathrm{A} \beta_{34}$ is a $C$-terminal-truncated isoform of $A \beta$ that is an intermediate in the $A \beta$ degradation pathway. Its production results from either matrix metalloprotease activity or from the degradation of $A b_{40}$ and $\mathrm{Ab}_{42}$ by $\gamma$-secretase [79]. The cleavage of $A \beta_{40 / 42}$ by beta-site amyloid precursor protein-cleaving enzyme 1 (BACE1) also produces $A \beta_{34}$ [80]. Braak staging of post-mortem hippocampal and cortical brain tissue from $\mathrm{AD}$ patients revealed that $\mathrm{Ab}_{34}$ immunoreactivity was confined to pericyte-associated brain capillaries in the early stages of $\mathrm{AD}$ [81]. This pericyte-associated $\mathrm{A} \beta_{34}$ immunoreactivity became largely undetectable at later stages of $\mathrm{AD}$. In addition, using primary human brain pericytes, the authors of this study also observed a dose-dependent increase in $A \beta_{34}$ levels upon exposure to recombinant $A \beta_{40}$ peptides that correlated with a reduction in both $A \beta_{40}$ uptake and BACE1 activity [82]. Finally, the authors proposed that $A \beta_{34}$ is generated by a novel BACE1-mediated $A \beta$ clearance pathway in the pericytes of brain capillaries, and that the impairment of this pathway may drive the pathogenesis in sporadic AD by disrupting amyloid clearance [81]. The role of brain 
pericytes in the trans-endothelial transport of $A \beta$ proteins and their clearance is unclear and will require further investigation. Nonetheless, disruptions in $B B B$ homeostasis that impact $A \beta$ degradation and/or clearance via the NVU can result in the long-term accumulation of $A \beta$ proteins, subsequently contributing to neurodegeneration and AD progression. Figure 3 shows a hypothetical model of how $A \beta$ protein accumulation affects the function of brain pericytes in the NVU. The effects include pericyte loss, pericyte toxicity, induction of ROS, and capillary constriction, all contributing to neuronal toxicity and neurodegeneration in AD.

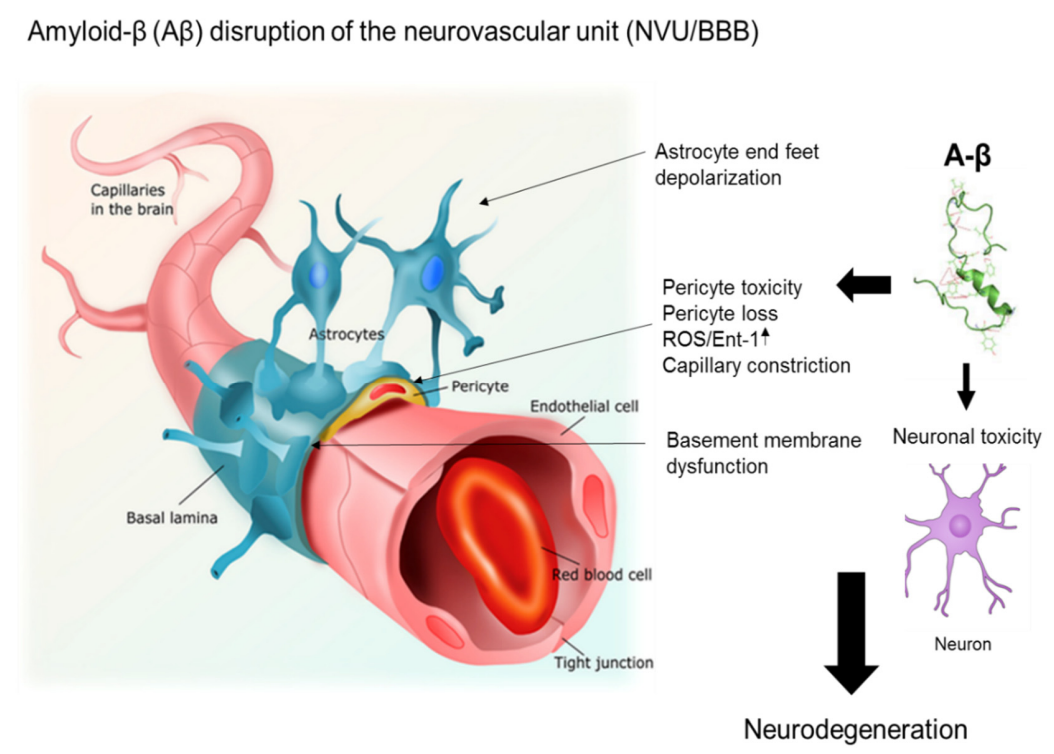

Figure 3. A model of the effects of amyloid beta $(A \beta)$ proteins on pericyte function in the neurovascular unit (NVU). The effects of $A \beta$ proteins on pericytes include pericyte loss, pericyte toxicity, induction of reactive oxygen species (ROS), and capillary constriction, all contributing to neuronal toxicity and neurodegeneration. Figure 3 was revised from previous studies by Alcendor [27]. For the original figure, I acknowledge Pearson Education Inc. (2014).

\section{A $\beta$ Proteins and Retinal Pericytes in the Ocular Compartment of AD Patients}

The inner blood-retinal barrier (IBRB) consists of retinal microvascular endothelial cells covered with tightly associated retinal pericytes and Müller cells; together, they form the retinal vascular unit (RVU) [82-85]. Retinal and brain pericytes have similar functions-both require regulation by PDGFR $\beta$ signaling for proper pericyte recruitment and adequate barrier formation $[86,87]$. Both AD and age-related macular degeneration (AMD) often occur among aging populations. Human retinal pericyte exposure and response to $A \beta$ proteins have not been extensively studied. This represents a knowledge gap that warrants further investigation.

Nonetheless, the retinal pathology observed in $\mathrm{AD}$ patients is similar to $\mathrm{A} \beta$ deposition observed in patients with AMD. Similarly, $A \beta$ accumulation observed in the brains of $A D$ patients also exists in the retinal compartment of both AD patients and patients with AMD [88,89]. ROS resulting from mitochondrial dysfunction are also present in both AD patients and patients with AMD. Recent studies demonstrated that long-term treatment with mitochondria-targeted antioxidant SkQ1 suppressed the development of AMD-like pathology in senescence-accelerated OXYS rats by reducing the level of $A \beta$ proteins and suppressing the activity of mTOR in the retina [90-92]. Findings from these studies revealed a connection between $\mathrm{AD}$ with $\mathrm{AMD}$ and may provide insights into the development of novel strategies for treating $\mathrm{AD}$. $\mathrm{A} \beta$ plaques also exist in the brains and retinas of animal models of $\mathrm{AD}$; in fact, the accumulation of $\mathrm{A} \beta$ proteins can occur in the retina before the brain [93-97]. As a result, animals with retinal $A \beta$ accumulation experience significant changes in vision $[98,99]$. This is because $\mathrm{A} \beta$ toxicity results in the upregulation of MCP- 1 and apoptotic markers in the ganglion cell layer [100-102], leading to microglia infiltration and astrogliosis in the retina. 
In a study by den Haan et al. that examined the presence of A $\beta$, pTau, and APP in the post-mortem retinas of $\mathrm{AD}$ patients and controls by immunohistochemistry, immunostaining for $\mathrm{A} \beta$ and APP yielded positive results in ganglion cells, amacrine cells, horizontal cells and Müller cells in both controls and $\mathrm{AD}$ cases [103]. A $\beta$ plaque development in the retinal tissue of $\mathrm{AD}$ patients has been controversial because the ocular pathologies observed can also be due to other confounding factors such as ocular hypertension, multiple sclerosis, and Parkinson's disease [88,93]. In other words, it is currently not possible to directly link $A \beta$ deposition in the retina to AD manifestation. Nonetheless, a study by Koronyo-Hamaoui et al. revealed the presence of $A \beta$ plaques in post-mortem retinal tissue, and that the formation of these plaques preceded plaque formation in the brain that correlated with AD progression [93].

Modern photonic imaging systems such as optical coherence tomography (OCT) could provide a non-invasive means for visualizing retinal changes in $\mathrm{AD}$ that occur before degenerative changes in the brain. The development of these ocular amyloid biomarkers for AMD could potentially provide unique diagnostic tools for AD especially at early stages, for monitoring AD disease progression, and for gauging the effects of novel treatment strategies. In a study by Ferrari et al. using OCT, they observed retinal neuroaxonal thinning in frontotemporal dementia, as seen in AD [104]. Changes in retinal nerve fiber layer (RNFL) thickness is thought to occur because of retrograde degeneration of the retinal ganglion cell axons, and these changes have been suggested to occur before memory is affected [105]. OCT appears to be a promising method to aid in the diagnosis of various neurodegenerative disorders, including AD. However, the clinical severity of AD and the overall RNFL thickness is not well established and will require further investigations [106]. Most recently, Szegedi et al. have shown anatomical and functional changes in the retina in patients with $\mathrm{AD}$ and mild cognitive impairment using OCT [107]. They found that, in patients with MCI and AD, arteriovenous differences in oxygen saturation, retinal blood flow and arterial vessel diameter was reduced, which suggests alterations in retinal oxygen metabolism in patients with $\mathrm{AD}$ [107]. In addition, in vivo two-photon microscopy (TPM) in mouse models of AD have revolutionized visual imaging in real time in the intact brain, such as for the examination of individual $A \beta$ plaques, and the effects of anti-amyloid therapies on plaque formation and growth [108]. TPM combined with fluorescent calcium indicators revealed hyperactivity-associated $A \beta$ deposition. This observation was found to be associated with cortical and hippocampal neurons that were revealed as a primary neuronal impairment [108].

\section{Strategies to Replace Pericytes in the CNS or Protect Them from the Effects of A $\beta$}

It would be interesting to determine if gene expression profiles of brain pericytes differ from those of pericytes in other microvascular compartments (eye, placenta, and kidney) upon exposure to $A \beta$ proteins. For instance, some pericytes may be unresponsive to the $\mathrm{A} \beta$-mediated generation of ROS and induction of endothelin-1. The analysis of gene expression profiles of different pericytes upon exposure to $A \beta$ proteins could help researchers identify pericyte populations that are unresponsive to $\mathrm{A} \beta$-mediated capillary constriction. This discovery would support the transfer of $A \beta$-nonresponsive pericytes from one microvascular compartment to another as a therapeutic intervention. To this end, Tachibana et al. examined the effects of pericytes on $A \beta$ metabolism using mouse mesenchymal stem cells that had been differentiated into pericytes and stereotaxically injected into the brains of APP/PS1 mice, an animal model for amyloid AD [109]. Upon implantation, the mice exhibited increased brain microcirculation, reduced levels of insoluble hippocampal $A \beta_{40}$ and $A \beta_{42}$ in the pericyte-injected hemisphere and reduced hippocampal $A \beta$ deposition [109]. This study suggests that cell-based therapies involving pericyte implantation may provide a novel approach to treating or limiting the progression of $\mathrm{AD}$.

Pericyte replacement is currently being investigated as a treatment option for non-proliferative diabetic retinopathy (NPDR). This condition presents in diabetic patients when their retinas exhibit microaneurysms, microhemorrhages, nerve fiber infarcts (also known as cotton wool spots), retinal edema, and intraretinal vascular abnormalities [110]. NPDR is also characterized by the loss 
of both pericytes and endothelial cells, resulting in a reduced number of functional blood vessels and the disruption of the BBB [110]. The treatment replaces pericytes lost in the early stages of NPDR with adult MSCs from the bone marrow that can differentiate into pericytes under certain conditions [111]. In this regard, the RETICELL clinical trial examined the intravitreal injection of adult bone marrow MSCs into patients with retinitis pigmentosa in an attempt to restore ocular function [112]. The fact that this treatment could improve the patients' quality of life, even temporarily, demonstrates the possibility of pericyte replacement as a viable treatment option [112]. Another strategy is to protect pericyte loss by preventing or limiting the generation of ROS that contribute to pericyte loss. Pigment epithelium-derived factor (PEDF), secreted by primary human adipocytes, is a potent antioxidant that is neurotrophic and antiangiogenic $[113,114]$. A study of recombinant PEDF applied topically to the eyes of diabetic Akita mice showed diminished pericyte death, vascular leakage, and inflammation in the retina [115]. Other potential therapeutic strategies to prevent pericyte loss include blocking the voltage-gated $\mathrm{Ca} 2+$ channels on the pericytes, a method that has been shown to slow ischemia-mediated capillary constriction by the pericytes [116]. In addition, thalidomide, despite its toxicity, has been shown to induce pericyte proliferation, recruit pericytes to capillaries, and induce vessel maturation by increasing the levels of PDGF-B homodimers in endothelial cells $[117,118]$. Additionally, thalidomide has been shown to reduce BBB leakiness in an AD animal model [119]. Moreover, thalidomide has been patented for use to prevent the loss of BBB function after radiation therapy [120].

\section{Conclusions}

Pericytes are multipotent cells of the vascular system. The interaction between endothelial cells and pericytes is essential for proper microvascular formation, development, stabilization, and maintenance. These cells also influence the chemical composition of the surrounding microenvironment to protect endothelial cells from potential harm. The dysregulation or loss of pericyte function can result in microvascular instability and pathological consequences.

Since pericyte death reliably indicates mild cognitive impairments, it is likely both a symptom and a potential cause of AD. Hypoxia affects mechanisms involving APP. In doing so, it leads to the increased production of $\beta$ - and $\gamma$-secretase, and, subsequently, increased $A \beta$ production. Therefore, pericyte loss due to $A \beta$ toxicity may be an early event in $A D$ progression, as pericyte loss reduces $C B F$ and thus creates hypoxic areas throughout the brain. In other words, pericyte loss contributes to neuronal dysfunction and neurodegeneration over time. Drugs targeting pathophysiological mechanisms including $A \beta$ or tau protein metabolism, mitochondrial dysfunction, oxidative stress, and inflammation have been unsuccessful in treating $\mathrm{AD}$. This strongly supports the notion that $\mathrm{AD}$ is a multifactorial disease that likely involves changes in the brain microvasculature and pericytes. These changes suggest that therapies aimed at maintaining normal pericyte function may preserve neuronal function by preventing the decrease in CBF and the loss of BBB function. Therefore, therapies that prevent capillary constriction by pericytes and pericyte death may promote the restoration of $\mathrm{CBF}$ and the maintenance of BBB function after ischemia.

Both pericyte loss and dysfunction are involved in the development of fibrosis, diabetic retinopathy, ischemic organ failure, pulmonary hypertension, Alzheimer's disease, Parkinson's disease, tumor growth, and metastasis. Animal models designed to develop therapies for pericyte loss or dysfunction have limitations. Mouse models often fail to reproduce the anatomical complexity of the human brain and its vascular systems that can contribute to misleading results in clinical trials. The phenotypic differences among pericyte populations and how these populations function requires further investigation. The lack of standardized methods and procedures for pericyte isolation and characterization limit their use in clinical trials [121]. Clinically, pericytes have been limited to regenerative medicine and mainly used for the repopulation of vascular grafts [122]. The limitations for pericyte use in clinical trials can be addressed in the future by the identification of tissue-specific 
phenotypes and functions, as well as the standardization of the isolation and purification of pericytes that can be reproducible and established in a clinical setting for pericyte-based therapies.

Author Contributions: D.J.A. wrote the review. The author have read and agreed to the published version of the manuscript

Funding: D.J.A. was supported by the Meharry Zika Startup Grant and a Research Centers in Minority Institutions (RCMI) grant (U54MD007586-01).

Acknowledgments: I thank Waldemar Popik and James E.K. Hildreth for reviewing and reading the manuscript. Editing services were provided by the Meharry Office of Scientific Editing and Publications (NIH S21MD000104).

Conflicts of Interest: The author declares no conflict of interest.

\section{References}

1. Hebert, L.E.; Weuve, J.; Scherr, P.A.; Evans, D.A. Alzheimer disease in the United States (2010-2050) estimated using the 2010 census. Neurology 2013, 80, 1778-1783. [CrossRef] [PubMed]

2. Alzheimer's Association. 2016 Alzheimer's disease facts and figures. Alzheimers Dement. 2016, 12, 459-509. [CrossRef] [PubMed]

3. Ellis, R.J.; Olichney, J.M.; Thal, L.J.; Mirra, S.S.; Morris, J.C.; Beekly, D.; Heyman, A. Cerebral amyloid angiopathy in the brains of patients with Alzheimer's disease: The CERAD experience, Part XV. Neurology 1996, 46, 1592-1596. [CrossRef] [PubMed]

4. Shinohara, M.; Murray, M.E.; Frank, R.D.; DeTure, M.; Yamazaki, Y.; Tachibana, M.; Atagi, Y.; Davis, M.D.; Liu, C.C.; Zhao, N.; et al. Impact of sex and APOE4 on cerebral amyloid angiopathy in Alzheimer's disease. Acta Neuropathol. 2016, 132, 225-234. [CrossRef] [PubMed]

5. Serrano-Pozo, A.; Frosch, M.P.; Masliah, E.; Hyman, B.T. Neuropathological alterations in Alzheimer disease. Cold Spring Harb. Perspect. Med. 2011, 1, a006189. [CrossRef]

6. Heneka, M.T.; Carson, M.J.; El Khoury, J.; Landreth, G.E.; Brosseron, F.; Feinstein, D.L.; Jacobs, A.H.; Wyss-Coray, T.; Vitorica, J.; Ransohoff, R.M.; et al. Neuroinflammation in Alzheimer's disease. Lancet Neurol. 2015, 14, 388-405. [CrossRef]

7. Spires-Jones, T.L.; Hyman, B.T. The intersection of amyloid beta and tau at synapses in Alzheimer's disease. Neuron 2014, 82, 756-771. [CrossRef]

8. Qiu, C.; Kivipelto, M.; von Strauss, E. Epidemiology of Alzheimer's disease: Occurrence, determinants, and strategies toward intervention. Dialogues Clin. Neurosci. 2009, 2, 111-128.

9. Kisler, K.; Nelson, A.R.; Montagne, A.; Zlokovic, B.V. Cerebral blood flow regulation and neurovascular dysfunction in Alzheimer disease. Nat. Rev. Neurosci. 2017, 7, 419-434. [CrossRef]

10. Iadecola, C. The Neurovascular Unit Coming of Age: A Journey through Neurovascular Coupling in Health and Disease. Neuron 2017, 1, 17-42. [CrossRef] [PubMed]

11. Zehendner, C.M.; White, R.; Hedrich, J.; Luhmann, H.J. A neurovascular blood-brain barrier in vitro model. Methods Mol. Biol. 2014, 1135, 403-413. [PubMed]

12. Muoio, V.; Persson, P.B.; Sendeski, M.M. The neurovascular unit-oncept review. Acta Physiol. (Oxf.) 2014, 4, 790-798. [CrossRef] [PubMed]

13. ElAli, A.; Thériault, P.; Rivest, S. The role of pericytes in neurovascular unit remodeling in brain disorders. Int. J. Mol. Sci. 2014, 4, 6453-6474. [CrossRef] [PubMed]

14. Armulik, A.; Genové, G.; Mäe, M.; Nisancioglu, M.H.; Wallgard, E.; Niaudet, C.; He, L.; Norlin, J.; Lindblom, P.; Strittmatter, K.; et al. Pericytes regulate the blood-brain barrier. Nature 2010, 468, 557-561. [CrossRef]

15. Hamilton, N.B.; Attwell, D.; Hall, C.N. Pericyte-mediated regulation of capillary diameter: A component of neurovascular coupling in health and disease. Front. Neuroenerg. 2010, 2, 1-14. [CrossRef]

16. Korn, C.; Augustin, H.G. Mechanisms of vessel pruning and regression. Dev. Cell 2015, 34, 5-17. [CrossRef]

17. Alcendor, D.J.; Charest, A.M.; Zhu, W.Q.; Vigil, H.E.; Knobel, S.M. Infection and upregulation of proinflammatory cytokines in human brain vascular pericytes by human cytomegalovirus. J. Neuroinflamm. 2012, 9, 95. [CrossRef]

18. Salmina, A.B.; Komleva, Y.K.; Lopatina, O.L.; Birbrair, A. Pericytes in Alzheimer's Disease: Novel Clues to Cerebral Amyloid Angiopathy Pathogenesis. Adv. Exp. Med. Biol. 2019, 1147, 147-166. 
19. Winkler, E.A.; Sagare, A.P.; Zlokovic, B.V. The pericyte: A forgotten cell type with important implications for Alzheimer's disease? Brain Pathol. 2014, 24, 371-386. [CrossRef]

20. Erickson, M.A.; Banks, W.A. Blood-brain barrier dysfunction as a cause and consequence of Alzheimer's disease. J. Cereb. Blood Flow Metab. 2013, 10, 1500-1513. [CrossRef]

21. Yamazaki, Y.; Kanekiyo, T. Blood-Brain Barrier Dysfunction and the Pathogenesis of Alzheimer's Disease. Int. J. Mol. Sci. 2017, 18, 1965. [CrossRef] [PubMed]

22. Sagare, A.P.; Bell, R.D.; Zlokovic, B.V. Neurovascular dysfunction and faulty amyloid $\beta$-peptide clearance in Alzheimer disease. Cold Spring Harb. Perspect. Med. 2012, 2, a011452. [CrossRef] [PubMed]

23. Sagare, A.P.; Bell, R.D.; Zlokovic, B.V. Neurovascular defects and faulty amyloid- $\beta$ vascular clearance in Alzheimer's disease. J. Alzheimers Dis. 2013, 33, S87-S100. [CrossRef] [PubMed]

24. Nortley, R.; Korte, N.; Izquierdo, P.; Hirunpattarasilp, C.; Mishra, A.; Jaunmuktane, Z.; Kyrargyri, V.; Pfeiffer, T.; Khennouf, L.; Madry, C.; et al. Amyloid $\beta$ oligomers constrict human capillaries in Alzheimer's disease via signaling to pericytes. Science 2019, 365, 6450. [CrossRef] [PubMed]

25. Gravina, S.A.; Ho, L.; Eckman, C.B.; Long, K.E.; Otvos, L., Jr.; Younkin, L.H.; Suzuki, N.; Younkin, S.G. Amyloid $\beta$ protein $(A \beta)$ in Alzheimer's disease brain. Biochemical and immunocytochemical analysis with antibodies specific for forms ending at A $\beta 40$ or A $\beta$ 42(43). J. Biol. Chem. 1995, 270, 7013-7016. [CrossRef] [PubMed]

26. Ma, Q.; Zhao, Z.; Sagare, A.P.; Wu, Y.; Wang, M.; Owens, N.C.; Verghese, P.B.; Herz, J.; Holtzman, D.M.; Zlokovic, B.V. Blood-brain barrier-associated pericytes internalize and clear aggregated amyloid- $\beta 42$ by LRP1-dependent apolipoprotein E isoform-specific mechanism. Mol. Neurodegener. 2018, 13, 57. [CrossRef]

27. Alcendor, D.J. Human Vascular Pericytes and Cytomegalovirus Pathobiology. Int. J. Mol. Sci. 2019, 6, 1456. [CrossRef]

28. Baranello, R.J.; Bharani, K.L.; Padmaraju, V.; Chopra, N.; Lahiri, D.K.; Greig, N.H.; Pappolla, A.M.; Sambamurti, K. Amyloid- $\beta$ protein clearance and degradation (ABCD) pathways and their role in Alzheimer's disease. Curr. Alzheimer Res. 2015, 32-46. [CrossRef]

29. Ruzali, W.A.; Kehoe, P.G.; Love, S. Influence of LRP-1 and apolipoprotein E on amyloid- $\beta$ uptake and toxicity to cerebrovascular smooth muscle cells. J. Alzheimers Dis. 2013, 1, 95-110. [CrossRef]

30. Sagare, A.P.; Deane, R.; Zetterberg, H.; Wallin, A.; Blennow, K.; Zlokovic, B.V. Impaired lipoprotein receptor-mediated peripheral binding of plasma amyloid- $\beta$ is an early biomarker for mild cognitive impairment preceding Alzheimer's disease. J. Alzheimers. Dis. 2011, 24, 25-34. [CrossRef]

31. Shinohara, M.; Fujioka, S.; Murray, M.E.; Wojtas, A.; Baker, M.; Rovelet-Lecrux, A.; Rademakers, R.; Das, P.; Parisi, J.E.; Graff-Radford, N.R.; et al. Regional distribution of synaptic markers and APP correlate with distinct clinicopathological features in sporadic and familial Alzheimer's disease. Brain 2014, 137, 1533-1549. [CrossRef] [PubMed]

32. Virchow, R. Zur cellulose. Arch. Pathol. 1854, 6, 416-426. [CrossRef]

33. Sipe, J.D.; Cohen, A.S. Review: History of the amyloid fibril. J. Struct. Biol. 2000, 130, 88-98. [CrossRef] [PubMed]

34. Friedreich, N.; Kekulé, A. Zur amyloidfrage. Virchows Arch. 1859, 16, 50-65. [CrossRef]

35. Eisenberg, D.; Jucker, M. The amyloid state of proteins in human diseases. Cell 2012, 148, 1188-1203. [CrossRef] [PubMed]

36. Westermark, P.; Benson, M.D.; Buxbaum, J.N.; Cohen, A.S.; Frangione, B.; Ikeda, S.-I.; Masters, C.L.; Merlini, G.; Saraiva, M.J.; Sipe, J.D. Amyloid: Toward terminology clarification. Report from the Nomenclature Committee of the International Society of Amyloidosis. Amyloid 2005, 12, 1-4. [CrossRef]

37. Iadanza, M.G.; Jackson, M.P.; Hewitt, E.W.; Ranson, N.A.; Radford, S.E. A new era for understanding amyloid structures and disease. Nat. Rev. Mol. Cell Biol. 2018, 12, 755-773. [CrossRef]

38. Kayed, R.; Head, E.; Sarsoza, F.; Saing, T.; Cotman, C.W.; Necula, M.; Margol, L.; Wu, J.; Breydo, L.; Thompson, J.L.; et al. Fibril specific, conformation dependent antibodies recognize a generic epitope common to amyloid fibrils and fibrillary oligomers that is absent in prefibrillar oligomers. Mol. Neurodegener. 2007, 2, 18. [CrossRef]

39. Kayed, R.; Pensalfini, A.; Margol, L.; Sokolov, Y.; Sarsoza, F.; Head, E.; Hall, J.; Glabe, C. Annular protofibrils are a structurally and functionally distinct typeof amyloid oligomer. J. Biol. Chem. 2009, 284, 4230-4237. [CrossRef] 
40. Glabe, C.G. Structural classification of toxic amyloid oligomers. J. Biol. Chem. 2008, 283, $29639-29643$. [CrossRef]

41. Ma, B.; Nussinov, R. Polymorphic C-terminal beta-sheet interactions determine the formation of fibril or amyloid beta-derived diffusible ligand-like globulomer for the alzheimer A $\{$ beta $\} 42$ dodecamer. J. Biol. Chem. 2010, 285, 37102-37110. [CrossRef] [PubMed]

42. Breydo, L.; Kurouski, D.; Rasool, S.; Milton, S.; Wu, J.W.; Uversky, V.N.; Lednev, I.K.; Glabe, C.G. Structural differences between amyloid beta oligomers. Biochem. Biophys. Res. Commun. 2016, 4, 700-705. [CrossRef] [PubMed]

43. Protein Data Bank. Yearly Growth of Total Structures. 2018. Available online: http://www.rcsb.org/pdb/ statistics/contentGrowthChart.do?content=total (accessed on 20 September 2018).

44. Alzheimer, A. Über einen eigenartigen schweren Erkrankungsproze $\beta$ der Hirnrincle. Neurol. Cent. 1906, 25, 1134 .

45. Alzheimer, A. Über eine eigenartige Erkrankung der Hirnrinde. Allg. Z. Psychiatr. Psych. Gerichtl. Med. 1907, 641, 46-48.

46. Lott, I.T.; Head, E. Alzheimer disease and Down syndrome: Factors in pathogenesis. Neurobiol. Aging 2005, 26, 383-389. [CrossRef] [PubMed]

47. Pearson, H.A.; Peers, C. Physiological roles for amyloid beta peptides. J. Physiol. 2006, 575, 5-10. [CrossRef]

48. Du, W.J.; Guo, J.-J.; Gao, M.-T.; Hu, S.-Q.; Dong, X.-Y.; Han, Y.-F.; Liu, F.-F.; Jiang, S.; Sun, Y. Brazilin inhibits amyloid beta-protein fibrillogenesis, remodels amyloid fibrils and reduces amyloid cytotoxicity. Sci. Rep. 2015, 5, 7992. [CrossRef]

49. Eberth, C.J. Handbuch der Lehre von der Gewegen des Menschen und der Tiere; Engelmann: Leipzig, Germany, 1871; Volume 1.

50. Rouget, C. Me'moire sur le de'veloppement, la structure et les propriete's physiologiques des capillaires sanguins et lymphatiques. Arch. Physiol. Norm. Path. 1873, 5, 603-663.

51. Zimmermann, K.W. Der feinere Bau der Blutkapillaren. Z. Anat. Entwicklungsgesch. 1923, 68, 29-109. [CrossRef]

52. Attwell, D.; Mishra, A.; Hall, C.N.; O'Farrell, F.M.; Dalkara, T. What is a pericyte? J. Cereb. Blood Flow Metab. 2016, 2, 451-455. [CrossRef]

53. Smyth, L.C.D.; Rustenhoven, J.; Scotter, E.L.; Schweder, P.; Faull, R.L.M.; Park, T.I.H.; Dragunow, M. Markers for human brain pericytes and smooth muscle cells. J. Chem. Neuroanat. 2018, 92, 48-60. [CrossRef] [PubMed]

54. Frank, R.N.; Turczyn, T.J.; Das, A. Pericyte coverage of retinal and cerebral capillaries. Investig. Ophthalmol. Vis. Sci. 1990, 31, 999-1007.

55. Frank, R.N.; Dutta, S.; Mancini, M.A. Pericyte coverage is greater in the retinal than in the cerebral capillaries of the rat. Investig. Ophthalmol. Vis. Sci. 1987, 28, 1086-1091.

56. Gaengel, K.; Genove, G.; Armulik, A.; Betsholtz, C. Endothelial-mural cell signaling in vascular development and angiogenesis. Arterioscler. Thromb. Vasc. Biol. 2009, 29, 630-638. [CrossRef] [PubMed]

57. Hellstrom, M.; Kalen, M.; Lindahl, P.; Abramsson, A.; Betsholtz, C. Role of PDGF-B and PDGFR- $\beta$ in recruitment of vascular smooth muscle cells and pericytes during embryonic blood vessel formation in the mouse. Development 1999, 126, 3047-3055.

58. Hawkins, B.T.; Davis, T.P. The Blood-Brain Barrier/Neurovascular Unit in Health and Disease. Pharmacol. Rev. 2005, 2, 173-185. [CrossRef]

59. Olson, L.E.; Soriano, P. PDGFR $\beta$ signaling regulates mural cell plasticity and inhibits fat development. Dev. Cell 2011, 6, 815-826. [CrossRef]

60. Hellström, M.; Gerhardt, H.; Kalén, M.; Li, X.; Eriksson, U.; Wolburg, H.; Betsholtz, C. Lack of pericytes leads to endothelial hyperplasia and abnormal vascular morphogenesis. J. Cell Biol. 2001, 3, 543-553. [CrossRef]

61. Dahlgren, K.N.; Manelli, A.M.; Stine, W.B., Jr.; Baker, L.K.; Krafft, G.A.; LaDu, M.J. Oligomeric and fibrillar species of amyloid-beta peptides differentially affect neuronal viability. J. Biol. Chem. 2002, 277, 32046-32053. [CrossRef]

62. Sengillo, J.D.; Winkler, E.A.; Walker, C.T.; Sullivan, J.S.; Johnson, M.; Zlokovic, B.V. Deficiency in mural vascular cells coincides with blood-brain barrier disruption in Alzheimer's disease. Brain Pathol. 2013, 23, 303-310. [CrossRef] 
63. Miners, J.S.; Schulz, I.; Love, S. Differing associations between A $\beta$ accumulation, hypoperfusion, blood-brain barrier dysfunction and loss of PDGFRB pericyte marker in the precuneus and parietal white matter in Alzheimer's disease. J. Cereb. Blood Flow Metab. 2018, 1, 103-115. [CrossRef] [PubMed]

64. Wilhelmus, M.M.; Otte-Holler, I.; van Triel, J.J.; Veerhuis, R.; Maat-Schieman, M.L.; Bu, G.; Verbeek, M.M. Lipoprotein receptor-related protein-1 mediates amyloid-beta-mediated cell death of cerebrovascular cells. Am. J. Pathol. 2007, 171, 1989-1999. [CrossRef] [PubMed]

65. Schultz, N.; Nielsen, H.M.; Minthon, L.; Wennstrom, M. Involvement of matrix metalloproteinase-9 in amyloid-beta 1-42-induced shedding of the pericyte proteoglycan NG2. J. Neuropathol. Exp. Neurol. 2014, 73, 684-692. [CrossRef] [PubMed]

66. Maia, L.F.; Mackenzie, I.R.; Feldman, H.H. Clinical phenotypes of cerebral amyloid angiopathy. J. Neurol. Sci. 2007, 257, 23-30. [CrossRef] [PubMed]

67. Verbeek, M.M.; Van Nostrand, W.E.; Otte-Holler, I.; Wesseling, P.; De Waal, R.M. Amyloid-beta-induced degeneration of human brain pericytes is dependent on the apolipoprotein E genotype. Ann. N. Y. Acad. Sci. 2000, 903, 187-199. [CrossRef] [PubMed]

68. Verbeek, M.M.; de Waal, R.M.; Schipper, J.J.; Van Nostrand, W.E. Rapid degeneration of cultured human brain pericytes by amyloid beta protein. J. Neurochem. 1997, 68, 1135-1141. [CrossRef]

69. Schultz, N.; Brännström, K.; Byman, E.; Moussaud, S.; Nielsen, H.M.; Netherlands Brain Bank; Olofsson, A.; Wennström, M. Amyloid-beta 1-40 is associated with alterations in NG2+ pericyte population ex vivo and in vitro. Aging Cell 2018, 3, e12728. [CrossRef]

70. Roberts, K.F.; Elbert, D.L.; Kasten, T.P.; Patterson, B.W.; Sigurdson, W.C.; Connors, R.E.; Ovod, V.; Munsell, L.Y.; Mawuenyega, K.G.; Miller-Thomas, M.M.; et al. Amyloidbeta efflux from the central nervous system into the plasma. Ann. Neurol. 2014, 76, 837-844. [CrossRef]

71. Tarasoff-Conway, J.M.; Carare, R.O.; Osorio, R.S.; Glodzik, L.; Butler, T.; Fieremans, E.; Axel, L.; Rusinek, H.; Nicholson, C.; Zlokovic, B.V.; et al. Clearance systems in the brain-implications for Alzheimer disease. Nat. Rev. Neurol. 2015, 11, 457-470. [CrossRef]

72. Holtzman, D.M.; Herz, J.; Bu, G. Apolipoprotein E and apolipoprotein E receptors: Normal biology and roles in Alzheimer disease. Cold Spring Harb. Perspect. Med. 2012, 2, a006312. [CrossRef]

73. Kanekiyo, T.; Xu, H.; Bu, G. ApoE and Abeta in Alzheimer's disease: Accidental encounters or partners? Neuron 2014, 81, 740-754. [CrossRef] [PubMed]

74. Bell, R.D.; Sagare, A.P.; Friedman, A.E.; Bedi, G.S.; Holtzman, D.M.; Deane, R.; Zlokovic, B.V. Transport pathways for clearance of human Alzheimer's amyloid betapeptide and apolipoproteins $\mathrm{E}$ and $\mathrm{J}$ in the mouse central nervous system. J. Cereb. Blood Flow Metab. 2007, 27, 909-918. [CrossRef] [PubMed]

75. Shibata, M.; Yamada, S.; Kumar, S.R.; Calero, M.; Bading, J.; Frangione, B.; Holtzman, D.M.; Miller, C.A.; Strickland, D.K.; Ghiso, J.; et al. Clearance of Alzheimer's amyloid-ss (1-40) peptide from brain by LDL receptor-related protein-1 at the blood-brain barrier. J. Clin. Investig. 2000, 106, 1489-1499. [CrossRef] [PubMed]

76. Deane, R.; Wu, Z.; Sagare, A.; Davis, J.; Du Yan, S.; Hamm, K.; Xu, F.; Parisi, M.; LaRue, B.; Hu, H.W.; et al. LRP/amyloid beta-peptide interaction mediates differential brain efflux of Abeta isoforms. Neuron 2004, 43, 333-344. [CrossRef]

77. Zhao, Z.; Sagare, A.P.; Ma, Q.; Halliday, M.R.; Kong, P.; Kisler, K.; Winkler, E.A.; Ramanathan, A.; Kanekiyo, T.; $\mathrm{Bu}, \mathrm{G}$; et al. Central role for PICALM in amyloid-beta blood-brain barrier transcytosis and clearance. Nat. Neurosci. 2015, 18, 978-987. [CrossRef]

78. Casey, C.S.; Atagi, Y.; Yamazaki, Y.; Shinohara, M.; Tachibana, M.; Fu, Y.; Bu, G.; Kanekiyo, T. Apolipoprotein E Inhibits Cerebrovascular Pericyte Mobility through a RhoA Protein-mediated Pathway. J. Biol. Chem. 2015, 22, 14208-14217. [CrossRef] [PubMed]

79. Hernandez-Guillamon, M.; Mawhirt, S.; Blais, S.; Montaner, J.; Neubert, T.A.; Rostagno, A.; Ghiso, J. Sequential Amyloid- $\beta$ Degradation by the Matrix Metalloproteases MMP-2 and MMP-9. J. Biol. Chem. 2015, 24, 15078-15091. [CrossRef]

80. Olsson, F.; Schmidt, S.; Althoff, V.; Munter, L.M.; Jin, S.; Rosqvist, S.; Lendahl, U.; Multhaup, G.; Lundkvist, J. Characterization of intermediate steps in amyloid beta $(\mathrm{A} \beta)$ production under near-native conditions. J. Biol. Chem. 2014, 3, 1540-1550. [CrossRef] 
81. Fluhrer, R.; Multhaup, G.; Schlicksupp, A.; Okochi, M.; Takeda, M.; Lammich, S.; Willem, M.; Westmeyer, G.; Bode, W.; Walter, J.; et al. Identification of a beta-secretase activity, which truncates amyloid beta-peptide after its presenilin-dependent generation. J. Biol. Chem. 2003, 8, 5531-5538. [CrossRef]

82. Kirabali, T.; Rigotti, S.; Siccoli, A.; Liebsch, F.; Shobo, A.; Hock, C.; Nitsch, R.M.; Multhaup, G.; Kulic, L. The amyloid- $\beta$ degradation intermediate $A \beta 34$ is pericyte-associated and reduced in brain capillaries of patients with Alzheimer's disease. Acta Neuropathol. Commun. 2019, 1, 194. [CrossRef]

83. Díaz-Coránguez, M.; Ramos, C.; Antonetti, D.A. The inner blood-retinal barrier: Cellular basis and development. Vis. Res. 2017, 139, 123-137. [CrossRef] [PubMed]

84. Fresta, C.G.; Fidilio, A.; Caruso, G.; Caraci, F.; Giblin, F.J.; Leggio, G.M.; Salomone, S.; Drago, F.; Bucolo, C. A New Human Blood-Retinal Barrier Model Based on Endothelial Cells, Pericytes, and Astrocytes. Int. J. Mol. Sci. 2020, 21, 1636. [CrossRef] [PubMed]

85. Hosoya, K.; Tachikawa, M. The inner blood-retinal barrier: Molecular structure and transport biology. Adv. Exp. Med. Biol. 2012, 763, 85-104. [PubMed]

86. Wilkerson, I.; Laban, J.; Mitchell, J.M.; Sheibani, N.; Alcendor, D.J. Retinal pericytes and cytomegalovirus infectivity: Implications for HCMV-induced retinopathy and congenital ocular disease. J. Neuroinflamm. 2015, 12, 2. [CrossRef] [PubMed]

87. Benjamin, L.E.; Hemo, I.; Keshet, E. A plasticity window for blood vessel remodelling is defined by pericyte coverage of the preformed endothelial network and is regulated by PDGF-B and VEGF. Development 1998, 9, 1591-1598.

88. Enge, M.; Bjarnegård, M.; Gerhardt, H.; Gustafsson, E.; Kalén, M.; Asker, N.; Hammes, H.P.; Shani, M.; Fässler, R.; Betsholtz, C. Endothelium-specific platelet-derived growth factor-B ablation mimics diabetic retinopathy. EMBO J. 2002, 16, 4307-4316. [CrossRef]

89. Ong, S.S.; Proia, A.D.; Whitson, H.E.; Farsiu, S.; Doraiswamy, P.M.; Lad, E.M. Ocular amyloid imaging at the crossroad of Alzheimer's disease and age-related macular degeneration: Implications for diagnosis and therapy. J. Neurol. 2019, 7, 1566-1577. [CrossRef]

90. Kaarniranta, K.; Salminen, A.; Haapasalo, A.; Soininen, H.; Hiltunen, M. Age-related macular degeneration (AMD): Alzheimer's disease in the eye? J. Alzheimers Dis. 2011, 24, 615-631. [CrossRef]

91. Muraleva, N.A.; Kozhevnikova, O.S.; Fursova, A.Z.; Kolosova, N.G. Suppression of AMD-Like Pathology by Mitochondria-Targeted Antioxidant SkQ1 Is Associated with a Decrease in the Accumulation of Amyloid $\beta$ and in mTOR Activity. Antioxidants 2019, 6, 177. [CrossRef]

92. Kolosova, N.G.; Tyumentsev, M.A.; Muraleva, N.A.; Kiseleva, E.; Vitovtov, A.O.; Stefanova, N.A. Antioxidant SkQ1 Alleviates Signs of Alzheimer's Disease-like Pathology in Old OXYS Rats by Reversing Mitochondrial Deterioration. Curr. Alzheimer Res. 2017, 12, 1283-1292. [CrossRef]

93. Stefanova, N.A.; Muraleva, N.A.; Maksimova, K.Y.; Rudnitskaya, E.A.; Kiseleva, E.; Telegina, D.V.; Kolosova, N.G. An antioxidant specifically targeting mitochondria delays progression of Alzheimer's disease-like pathology. Aging (Albany N. Y.) 2016, 8, 2713-2733. [CrossRef] [PubMed]

94. Koronyo-Hamaoui, M.; Koronyo, Y.; Ljubimov, A.V.; Miller, C.A.; Ko, M.K.; Black, K.L.; Schwartz, M.; Farkas, D.L. Identification of amyloid plaques in retinas from Alzheimer's patients and noninvasive in vivo optical imaging of retinal plaques in a mouse model. Neuroimage 2011, 54 (Suppl. 1), S204-S217. [CrossRef] [PubMed]

95. Schultz, N.; Byman, E. Netherlands Brain Bank, Wennström M1. Levels of Retinal Amyloid- $\beta$ Correlate with Levels of Retinal IAPP and Hippocampal Amyloid- $\beta$ in Neuropathologically Evaluated Individuals. J. Alzheimers. Dis. 2020, 3, 1201-1209.

96. Salobrar-García, E.; de Hoz, R.; Ramírez, A.I.; López-Cuenca, I.; Rojas, P.; Vazirani, R.; Amarante, C.; Yubero, R.; Gil, P.; Pinazo-Durán, M.D.; et al. Changes in visual function and retinal structure in the progression of Alzheimer's disease. PLoS ONE 2019, 8, e0220535. [CrossRef] [PubMed]

97. Williams, P.A.; Thirgood, R.A.; Oliphant, H.; Frizzati, A.; Littlewood, E.; Votruba, M.; Good, M.A.; Williams, J.; Morgan, J.E. Retinal ganglion cell dendritic degeneration in a mouse model of Alzheimer's disease. Neurobiol. Aging 2013, 7, 1799-1806. [CrossRef]

98. Liu, B.; Rasool, S.; Yang, Z.; Glabe, C.G.; Schreiber, S.S.; Ge, J.; Tan, Z. Amyloid-peptide vaccinations reduce \{beta\}-amyloid plaques but exacerbate vascular deposition and inflammation in the retina of Alzheimer's transgenic mice. Am. J. Pathol. 2009, 5, 2099-2110. [CrossRef] 
99. Hale, G.; Good, M. Impaired visuospatial recognition memory but normal object novelty detection and relative familiarity judgments in adult mice expressing the APPswe Alzheimer's disease mutation. Behav. Neurosci. 2005, 4, 884-891. [CrossRef]

100. Perez, S.E.; Lumayag, S.; Kovacs, B.; Mufson, E.J.; Xu, S. Betaamyloid deposition and functional impairment in the retina of the APPswe/PS1DeltaE9 transgenic mouse model of Alzheimer's disease. Investig. Ophthalmol. Vis. Sci. 2009, 2, 793-800. [CrossRef]

101. Ning, A.; Cui, J.; To, E.; Ashe, K.H.; Matsubara, J. Amyloidbeta deposits lead to retinal degeneration in a mouse model of Alzheimer disease. Investig. Ophthalmol. Vis. Sci. 2008, 11, 5136-5143. [CrossRef]

102. Edwards, M.M.; Rodriguez, J.J.; Gutierrez-Lanza, R.; Yates, J.; Verkhratsky, A.; Lutty, G.A. Retinal macroglia changes in a triple transgenic mouse model of Alzheimer's disease. Exp. Eye Res. 2014, 127, 252-260. [CrossRef]

103. Den Haan, J.; Morrema, T.H.J.; Verbraak, F.D.; de Boer, J.F.; Scheltens, P.; Rozemuller, A.J.; Bergen, A.A.B.; Bouwman, F.H.; Hoozemans, J.J. Amyloid-beta and phosphorylated tau in post-mortem Alzheimer's disease retinas. Acta Neuropathol. Commun. 2018, 1, 147. [CrossRef] [PubMed]

104. Ferrari, L.; Huang, S.C.; Magnani, G.; Ambrosi, A.; Comi, G.; Leocani, L. Optical Coherence Tomography Reveals Retinal Neuroaxonal Thinning in Frontotemporal Dementia as in Alzheimer's Disease. J. Alzheimers Dis. 2017, 3, 1101-1107. [CrossRef] [PubMed]

105. Ascaso, F.J.; Cruz, N.; Modrego, P.J.; Lopez-Anton, R.; Santabarbara, J.; Pascual, L.F. Retinal alterations in mild cognitive impairment and Alzheimer's disease: An optical coherence tomography study. J. Neurol. 2014, 261, 1522-1530. [CrossRef] [PubMed]

106. McGrory, S.; Cameron, J.R.; Pellegrini, E.; Warren, C.; Doubal, F.N.; Deary, I.J.; Dhillon, B.; Wardlaw, J.M.; Trucco, E.; MacGillivray, T.J. The application of retinal fundus camera imaging in dementia: A systematic review. Alzheimers Dement. (Amst.) 2016, 6, 91-107. [CrossRef] [PubMed]

107. Szegedi, S.; Dal-Bianco, P.; Stögmann, E.; Traub-Weidinger, T.; Rainer, M.; Masching, A.; Schmidl, D.; Werkmeister, R.M.; Chua, J.; Schmetterer, L.; et al. Anatomical and functional changes in the retina in patients with Alzheimer's disease and mild cognitive impairment. Acta Ophthalmol. 2020. [CrossRef] [PubMed]

108. Busche, M.A. In Vivo Two-Photon Calcium Imaging of Hippocampal Neurons in Alzheimer Mouse Models. Methods Mol. Biol. 2018, 1750, 341-351.

109. Tachibana, M.; Yamazaki, Y.; Liu, C.C.; Bu, G.; Kanekiyo, T. Pericyte, implantation in the brain enhances cerebral blood flow and reduces amyloid- $\beta$ pathology in amyloid model mice. Exp. Neurol. 2018, 300, $13-21$. [CrossRef]

110. Ferland-McCollough, D.; Slater, S.; Richard, J.; Reni, C.; Mangialardi, G. Pericytes, an overlooked player in vascular pathobiology. Pharmacol. Ther. 2017, 171,30-42. [CrossRef]

111. Caplan, A.I. Adult mesenchymal stem cells: When, where, and how. Stem Cells Int. 2015, 2015, 628767. [CrossRef]

112. Siqueira, R.C.; Messias, A.; Messias, K.; Arcieri, R.S.; Ruiz, M.A.; Souza, N.F.; Jorge, R. Quality of life in patients with retinitis pigmentosa submitted to intravitreal use of bone marrow-derived stem cells (Reticell-clinical trial). Stem Cell Res. Ther. 2015, 6, 29. [CrossRef]

113. Yamagishi, S.; Inagaki, Y.; Amano, S.; Okamoto, T.; Takeuchi, M.; Makita, Z. Pigment epithelium-derived factor protects cultured retinal pericytes from advanced glycation end product-induced injury through its antioxidative properties. Biochem. Biophys. Res. Commun. 2002, 296, 877-882. [CrossRef]

114. Zhang, S.X.; Wang, J.J.; Gao, G.; Parke, K.; Ma, J.X. Pigment epithelium-derived factor downregulates vascular endothelial growth factor (VEGF) expression and inhibits VEGF-VEGF receptor 2 binding in diabetic retinopathy. J. Mol. Endocrinol. 2006, 37, 1-12. [CrossRef] [PubMed]

115. Liu, Y.; Leo, L.F.; McGregor, C.; Grivitishvili, A.; Barnstable, C.J.; Tombran-Tink, J. Pigment epithelium-derived factor (PEDF) peptide eye drops reduce inflammation, cell death and vascular leakage in diabetic retinopathy in Ins2(Akita) mice. Mol. Med. 2012, 18, 1387-1401. [CrossRef] [PubMed]

116. Sakagami, K.; Wu, D.M.; Puro, D.G. Physiology of rat retinal pericytes: Modulation of ion channel activity by serum-derived molecules. J. Physiol. 1999, 3, 637-650. [CrossRef] [PubMed]

117. Franks, M.E.; Macpherson, G.R.; Figg, W.D. Thalidomide. Lancet 2004, 363, 1802-1811. [CrossRef]

118. Lebrin, F.; Srun, S.; Raymond, K.; Martin, S.; van den Brink, S.; Freitas, C.; Breant, C.; Mathivet, T.; Larrivee, B.; Thomas, J.L.; et al. Thalidomide stimulates vessel maturation and reduces epistaxis in individuals with hereditary hemorrhagic telangiectasia. Nat. Med. 2010, 16, 420-428. [CrossRef] [PubMed] 
119. Ryu, J.K.; McLarnon, J.G. Thalidomide inhibition of perturbed vasculature and glial-derived tumor necrosis factor-alpha in an animal model of inflamed Alzheimer's disease brain. Neurobiol. Dis. 2008, 29, $254-266$. [CrossRef] [PubMed]

120. Lebrin, F.; Soussain, C.; Thalgott, J. 2015. Available online: https://patents.google.com/patent/ WO2015107196A1/en (accessed on 6 August 2018).

121. Harrell, R.; Simovic, B.; Fellabaum, M.; Arsenijevic, A.; Djonov, V.; Volarevic, V. Molecular Mechanisms Underlying Therapeutic Potential of Pericytes. J. Biomed. Sci. 2018, 1, 21. [CrossRef]

122. Avolio, E.; Alvino, V.V.; Ghorbel, M.T.; Campagnolo, P. Perivascular cells and tissue engineering: Current applications and untapped potential. Pharmacol. Ther. 2017, 171, 83-92. [CrossRef]

C 2020 by the author. Licensee MDPI, Basel, Switzerland. This article is an open access article distributed under the terms and conditions of the Creative Commons Attribution (CC BY) license (http://creativecommons.org/licenses/by/4.0/). 